\title{
Chlamydial infection
}

Results of tests for Chlamydia in patients suffering from acute Reiter's disease compared with results of tests of the genital tract and rectum in patients with ocular infection due to TRIC agent

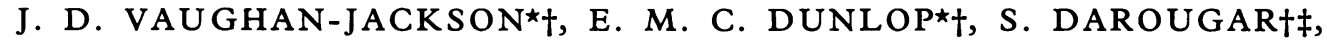 \\ R. ST. C. DWYER‡, AND B. R. JONES $†$ \\ From the Whitechapel Clinic, The London Hospital ${ }^{\star}$, and the Department of Clinical Ophthalmology $\dagger$, and the \\ Virus Laboratory $\ddagger$, Institute of Ophthalmology, London
}

The search for a causal agent of Reiter's disease has been pursued by workers in many centres. An unidentified agent was isolated in yolk sac from material from the urethra and conjunctiva of a patient suffering from Reiter's disease (Dunham, Rock, and Belt, 1947). Siboulet and Galistin (1962) reported the isolation of an unidentified agent in yolk sac from urethral scrapings from three patients. The findings in 22 patients suffering from Reiter's disease were reported by Schachter, Barnes, Jones, Engleman, and Mayer (1966); isolation in yolk sac had been attempted in eight cases, with positive results from urethral, conjunctival, or synovial material in five. In 1967 the group at the Institute of Ophthalmology and the Whitechapel Clinic of The London Hospital set up specifically to study oculogenital infection, reported results obtained up to that time and pointed out the possible danger of crosscontamination during isolation in yolk sac that rendered all but first passage isolates as possibly suspect (Harper, Dwyer, Garland, Jones, Treharne, Dunlop, Freedman, and Race, 1967). Twenty patients suffering from Reiter's disease had been tested; isolates had been obtained from urethral material from two and from synovial material from four, but no isolate had been obtained at the first passage in yolk sac (Dunlop, Freedman, Garland, Harper, Jones, Race, Du Toit, and Treharne, 1967).

The group adopted the technique of isolation of Chlamydia in cell culture using irradiated $\mathrm{McCoy}$ cells (Gordon, Magruder, Quan, and Arm, 1963; Gordon, Harper, Quan, Treharne, Dwyer, and Garland, 1969), which has been shown to be more sensitive than isolation in yolk sac and free from cross-contamination (Gordon and others, 1969; Dunlop, Hare, Darougar, Jones, and Rice, 1969; Darougar, Dwyer, Treharne, Harper, Garland, and Jones, 1971). Effective simplified techniques (Darougar, Kinnison, and Jones, 1971a, b; Darougar,

Received for publication September 8, 1972

Presented at the Jubilee Meeting of the M.S.S.V.D. held in Glasgow, June 8 to 11,1972
Jones, Kinnison, Vaughan-Jackson, and Dunlop 1972) have been used for testing material from patients suffering from Reiter's disease.

In addition to evidence of infection obtained by isolation of the agent, serological evidence of infection has been obtained. Schachter and others (1966) reported that three of the five isolate-positive patients and two others had significant titres of complementfixing anti-chlamydial group antibody as measured by a complement-fixation test (LGVCFT). The group at The London Hospital and Institute of Ophthalmology reported results of the LGVCFT in the cases of nineteen of the twenty patients tested by culture in yolk sac (Barwell, Dunlop, and Race, 1967). There was some fixation in eight cases only and this was complete at a titre of 1 in 4 or more in only five. These few positive results did not correlate with the results of culture. Schachter (1971) reported results of tests in 84 patients suffering from Reiter's disease compared with results in patients with proven chlamydial infections and controls. Significant titres were present in eleven (65 per cent.) of seventeen patients suffering from lymphogranuloma venereum (LGV), twenty (55 per cent.) of 38 men suffering from 'oculogenital' infection due to TRIC agent, eleven (42 per cent.) of 26 women suffering from 'oculogenital' infection due to TRIC agent, three (15 per cent.) of twenty patients suffering from urethritis due to 'TRIC agent', and eighteen ( 21 per cent.) of the 84 patients suffering from Reiter's disease. The titres were significantly higher in the group of patients suffering from Reiter's disease than in the other groups.

Further classification of the Chlamydia group of agents, beyond the division into subgroups $A$ and $B$ according to whether their inclusion bodies stain with iodine or not, has been achieved by immunofluorescence techniques. Sera from a small number of patients suffering from Reiter's disease have been tested by means of the micro-immunofluorescence test (micro-IF test) of Wang (Wang and Grayston, 1970; Wang, 1971; Wang and Grayston, 1971). 


\section{Patients and methods}

Findings in the cases of 29 men suffering from acute Reiter's disease who presented at The London Hospital or at Moorfields Eye Hospital, together with findings in the cases of fourteen of their sexual contacts, are reported. Only those patients in whose cases the diagnosis of Reiter's disease was certain are included. All patients were suffering from acute 'non-specific' urethritis at the time and from acute arthritis, affecting several joints in most cases; isolation was attempted from synovial fluid aspirated from effusions in the knees of nine patients. 24 had ocular manifestations or keratoderma or both; 22 had a raised erythrocyte sedimentation rate (ESR); the latex test was negative in all cases.

If possible, sexual contacts of patients suffering from Reiter's disease were examined and tested for genital infection; fourteen female contacts were examined. In no case was there a relevant history of recent therapy unlike the patients suffering from Reiter's disease, many of whom had already received antibiotics either for recent gonococcal urethritis or for the non-specific urethritis which is often the first feature of Reiter's disease to appear. Not only the tetracyclines and sulphonamides but also penicillin and related antibiotics have sufficient anti-chlamydial activity to render isolation of the agent difficult, if not impossible. Where the patient was under treatment no more anti-chlamydial preparations were given until material had been collected for cell culture.

The methods used for examination and for collection of material for cell culture have been reported by Dunlop and his colleagues $(1964,1965,1969,1971,1972){ }^{\star}$ In addition, serum was stored for testing by the micro-IF

^Dunlop, Jones, and Al-Hussaini (1964), Dunlop, Al-Hussaini, Garland, Treharne, Harper, and Jones (1965), Dunlop and others (1969), Dunlop, Hare, Darougar, and Jones (1971), Dunlop, VaughanJackson, and Darougar (1972), Dunlop, Vaughan-Jackson, Darougar, and Jones (1972). test; so far sera from ten patients only have been tested.

So far $\mathbf{4 5}$ patients suffering from infection of the eye by TRIC agent and thirty of their sexual contacts have been examined and tested for genital infection by Chlamydia using cell culture; the results of these tests are presented for comparison with those of the tests in the Reiter's disease group.

\section{Results}

29 men suffering from Reiter's disease were tested; Chlamydia was isolated from urethral material from three (Table I). Nineteen had received recent treatment with anti-chlamydial preparations; no isolate was obtained from them. Conjunctival material was collected from twelve patients and synovial fluid (from the knee) from nine; no isolate was obtained from these materials. Fourteen sexual contacts of these men suffering from Reiter's disease were tested (Table II). Contacts of each of the three men with positive urethral tests were examined; isolates were obtained from the cervix and urethra of one. No isolate was obtained from the contact of any man with negative urethral tests.

TABLE II Results of tests for Chlamydia of female sexual contacts of men suffering from acute Reiter's disease

\begin{tabular}{|c|c|c|}
\hline Group & $\begin{array}{l}\text { Number } \\
\text { tested }\end{array}$ & $\begin{array}{l}\text { Isolates } \\
\text { obtained }\end{array}$ \\
\hline $\begin{array}{l}\text { Contacts of men with positive urethral tests } \\
\text { Contacts of men with negative urethral tests }\end{array}$ & $\begin{array}{r}3 \\
11\end{array}$ & $\begin{array}{l}1 \\
0\end{array}$ \\
\hline Total & 14 & 1 \\
\hline
\end{tabular}

In no case did the LGVCFT show complete fixation at a titre of 1 in 16 or more (Table III).

TABLE I Results of cell culture for Chlamydia of material from men suffering from acute Reiter's disease

\begin{tabular}{|c|c|c|c|c|c|c|}
\hline Recent antibiotics & \multicolumn{2}{|c|}{ Urethral material } & \multicolumn{2}{|c|}{ Conjunctival material } & \multicolumn{2}{|c|}{ Synovial fluid } \\
\hline Untreated & 10 & 3 & 4 & 0 & 3 & 0 \\
\hline Total & 29 & 3 & 12 & 0 & 9 & 0 \\
\hline
\end{tabular}

T ABLE III Results of the LGVCFT: men suffering from Reiter's disease, contacts of men suffering from Reiter's disease

\begin{tabular}{|c|c|c|c|c|c|}
\hline \multirow{2}{*}{ Group } & \multirow{2}{*}{ Cell culture } & \multicolumn{3}{|l|}{ Fixation in LGVCFT } & \multirow[b]{2}{*}{ Number tested } \\
\hline & & Complete at 1 in 16 or more & Any & None & \\
\hline \multirow{2}{*}{$\begin{array}{l}\text { Men suffering from } \\
\text { Reiter's disease }\end{array}$} & Positive & 0 & 2 & 1 & 3 \\
\hline & Negative & 0 & 6 & 19 & 25 \\
\hline $\begin{array}{l}\text { Contacts of men } \\
\text { suffering from }\end{array}$ & Positive & 0 & 0 & 1 & 1 \\
\hline Reiter's disease & Negative & 0 & 1 & 12 & 13 \\
\hline
\end{tabular}


TABLE IV Results of the micro-IF test in ten men suffering from Reiter's disease

\begin{tabular}{|c|c|c|c|c|c|c|c|}
\hline $\begin{array}{l}\text { Result of } \\
\text { cell culture }\end{array}$ & $\begin{array}{l}\text { Number of } \\
\text { patients tested }\end{array}$ & \multicolumn{6}{|c|}{ Titres } \\
\hline $\begin{array}{l}\text { Positive } \\
\text { Negative }\end{array}$ & $\begin{array}{l}2 \\
8\end{array}$ & $\begin{array}{l}0 \\
2\end{array}$ & $\begin{array}{l}0 \\
0\end{array}$ & $\begin{array}{l}0 \\
1\end{array}$ & $\begin{array}{l}1 \\
1\end{array}$ & $\begin{array}{l}0 \\
2\end{array}$ & $\frac{1}{2}$ \\
\hline Total & 10 & 2 & 0 & 1 & 2 & 2 & 3 \\
\hline
\end{tabular}

Eight patients suffering from Reiter's disease showed fixation in this test to a lesser degree. In the three isolate-positive cases the test was reported as negative in one and as showing complete fixation at 1 in 8 in two, with partial fixation at 1 in 16 in one of these and at 1 in 32 in the other. One of the fourteen sexual contacts of the men suffering from Reiter's disease showed partial fixation at 1 in 8 . The remaining thirteen, which included the one isolate-positive contact, showed no fixation.

The micro-IF test was performed on sera from ten patients (Table IV), and titres of 1 in 16 or more were found in eight of them. Sera from two isolatepositive patients showed a titre of 1 in 32 in one, and of 1 in 128 in the other.

23 women, who had presented because of ocular infection due to TRIC agent, were examined (Table V).

TABLE $\mathrm{V}$ Results of cell culture of cervical, urethral, and rectal material from 23 women with proven ocular infection due to TRIC agent

\begin{tabular}{|c|c|c|}
\hline Site & Number tested & Isolate obtained \\
\hline $\begin{array}{l}\text { Cervix } \\
\text { Urethra } \\
\text { Rectum }\end{array}$ & $\begin{array}{l}21 \\
12 \\
21\end{array}$ & $\begin{array}{r}19 \\
7 \\
11\end{array}$ \\
\hline
\end{tabular}

Two young girls denied having had sexual intercourse and were found to be apparently virgo intacta, and cervical tests were not taken from them. Urethral tests were not performed routinely initially in the cases of women, so that the results of only twelve such tests are available.

22 men who presented because of ocular infection due to TRIC agent were tested, and isolates were obtained from ten (Table VI).

TABLE VI Results of cell culture of urethral material from 22 men with proven ocular infection due to TRIC agent

\begin{tabular}{ll}
\hline Number of patients tested & Isolates obtained \\
\hline 22 & $10^{\mathrm{a}}$ \\
\hline $\begin{array}{l}\text { an an additional four cases isolates were obtained from genital } \\
\text { material from female sexual partners }\end{array}$
\end{tabular}

Thirty sexual contacts (eleven men and nineteen women) of these patients with ocular infection were tested. Of the eleven men (Table VII), isolates were obtained from urethral material from six. Of the nineteen women (Table VIII), isolates were obtained from cervical material in eight; this included four in each of which an isolate had been obtained from the male partner's eye but not from his urethra. Isolates from urethra or rectum were obtained only in association with a cervical isolate.

TABLE VII Results of cell culture for Chlamydia of urethral material from male sexual contacts of women with proven ocular infection due to TRIC agent

\begin{tabular}{ll}
\hline Number of contacts tested & Isolates obtained \\
& 6
\end{tabular}

TABLE VIII Results of culture for Chlamydia of genital material from female sexual contacts of men with proven ocular infection due to TRIC agent

\begin{tabular}{llll}
\hline Group & $\begin{array}{l}\text { Number } \\
\text { tested }\end{array}$ & $\begin{array}{l}\text { Isolates } \\
\text { obtained }\end{array}$ \\
\cline { 1 - 2 } $\begin{array}{ll}\text { Contacts of men with positive urethral tests } \\
\text { Contacts of men with negative urethral tests }\end{array}$ & $\begin{array}{ll}7 \\
\text { Total }\end{array}$ & 4 \\
\cline { 1 - 2 } & 19 & 8 \\
\hline
\end{tabular}

The clinical findings, results of smears of cervical, urethral, and rectal material, of the LGVCFT and details of the presence of associated infections are shown in relation to isolation of agent (Table IX). Of the patients suffering from ocular infection due to TRIC agent, fifteen gave a history of vaginal discharge; isolates were obtained from fourteen of these; three had salpingitis, and isolates were obtained from two of them. Using an operating microscope, cervical mucosal changes ('follicles', papillary congestion, or scarring) were observed in eighteen patients; isolates were obtained from seventeen. A smear of cervical secretion was arbitrarily described as purulent if it contained at least 25 or more leucocytes per high-power $(1 / 12$ th) field. Cervical smears from seventeen patients were purulent; isolates were obtained from the cervix in all these cases. In only one case was the cervix normal and the cervical 
TABLE IX Findings in 23 women suffering from ocular infection due to TRIC agent and in nineteen sexual contacts of men with such infection

\begin{tabular}{|c|c|c|c|c|}
\hline \multirow[t]{2}{*}{ Clinical findings } & \multicolumn{2}{|c|}{$\begin{array}{l}\text { Female patients wuth ocular } \\
\text { infection due to TRIC agent }\end{array}$} & \multicolumn{2}{|c|}{$\begin{array}{l}\text { Female contacts of men with } \\
\text { ocular infection due to TRIC agent }\end{array}$} \\
\hline & Number tested & Isolate obtained & Number tested & Isolate obtained \\
\hline $\begin{array}{l}\text { History of vaginal discharge } \\
\text { Salpingitis }\end{array}$ & $\begin{array}{r}15 \\
3\end{array}$ & $\begin{array}{r}14 \\
2\end{array}$ & $\begin{array}{r}10 \\
4\end{array}$ & $\begin{array}{l}3 \\
2\end{array}$ \\
\hline $\begin{array}{l}\text { Cervix - Mucosal change } \\
\text { - Pus } 25 / \text { HPF or more } \\
\text { - Normal mucosa, no pus }\end{array}$ & $\begin{array}{r}18 \\
17 \\
1\end{array}$ & $\begin{array}{r}17 \\
17 \\
0\end{array}$ & $\begin{array}{r}17 \\
15 \\
0\end{array}$ & $\begin{array}{l}8 \\
5 \\
0\end{array}$ \\
\hline $\begin{array}{l}\text { Rectum - Mucosal change } \\
\text {-Pus 10/HPF or more } \\
\text { - Mucosa normal, no pus }\end{array}$ & $\begin{array}{r}11 \\
11 \\
8\end{array}$ & $\begin{array}{l}5 \\
8 \\
3\end{array}$ & $\begin{array}{r}1 \\
4 \\
14\end{array}$ & $\begin{array}{l}1 \\
2 \\
2\end{array}$ \\
\hline $\begin{array}{l}\text { LGVCFT fixation } \\
\text { Associated infection }\end{array}$ & $\begin{array}{r}9 \\
11\end{array}$ & $\begin{array}{r}7 \\
10\end{array}$ & $\begin{array}{l}6 \\
7\end{array}$ & $\begin{array}{l}4 \\
2\end{array}$ \\
\hline
\end{tabular}

at low level, highest $=$ complete fixation to 1 in 4

bandidiasis 11; trichomoniasis 6; previous syphilis 1

mucus non-purulent; no isolate was obtained in this case. Anorectal mucosal changes were present in eleven patients; isolates were obtained from rectal material from five of these. Smears of rectal material were arbitrarily described as purulent if they contained at least ten or more leucocytes per high-power field; such purulent smears were obtained from eleven patients, and isolates were obtained from rectal material from eight of them. Sera from nine patients showed complete fixation at 1 in 4 or less in the LGVCFT; isolates were obtained from seven of these. Eleven patients were found to be suffering from associated infection (candidiasis, trichomoniasis, or previous syphilis); isolates were obtained from ten of these.

Of the sexual contacts of men suffering from ocular infection due to TRIC agent, ten gave a history of vaginal discharge; isolates were obtained from three of these. Four contacts had salpingitis; isolates were obtained from two. Seventeen contacts showed changes in the cervical mucosa; isolates were obtained from eight of these. Smears of cervical secretion from fifteen contacts were purulent; isolates were obtained from five of them. The anorectal mucosa was abnormal in the case of one contact; an isolate was obtained from the rectum in this case. Smears of anorectal material were purulent in four cases; isolates were obtained from anorectal material from two of these. Eight patients with ocular infection due to TRIC agent and fourteen contacts of men with such infection were found to have normal anorectal mucosa and smears showing no pus; isolates were obtained from anorectal material from three patients with ocular infection and from two contacts. However, in these five cases, the anorectal mucosa itself appeared to be normal but was covered by mucoid material although this contained less than ten polymorphonuclear leucocytes per high-power field. Six contacts of men with ocular infection due to TRIC agent showed fixation in the LGVCFT to a

TABLE X Findings in 22 men suffering from ocular infection due to TRIC agent and in eleven sexual contacts of women with such infection

\begin{tabular}{|c|c|c|c|c|}
\hline \multirow[t]{2}{*}{ Clinical findings } & \multicolumn{2}{|c|}{$\begin{array}{l}\text { Men with ocular infection } \\
\text { due to TRIC agent }\end{array}$} & \multicolumn{2}{|c|}{$\begin{array}{l}\text { Male sexual contacts of women with } \\
\text { ocular infection due to TRIC agent }\end{array}$} \\
\hline & Number tested & Isolate obtained & Number tested & Isolate obtained \\
\hline $\begin{array}{l}\text { History of urethritis } \\
\text { Non-specific urethritis } \text { Marked }^{\mathrm{a}} \\
\text { Mild }^{-} \\
\text {No urethritis } \\
\text { Fixation in LGVCFT } \\
\text { Associated infection }\end{array}$ & $\begin{array}{r}7 \\
9 \\
8 \\
5 \\
14 \\
1\end{array}$ & $\begin{array}{l}4 \\
8 \\
2 \\
0 \\
8 \\
0\end{array}$ & $\begin{array}{l}2 \\
3 \\
7 \\
1 \\
2 \\
0\end{array}$ & $\begin{array}{l}1 \\
2 \\
4 \\
0 \\
0\end{array}$ \\
\hline
\end{tabular}

a Urethral smear containing more than 50 polymorphonuclear leucocytes per high-power field

bHighest $=$ complete fixation to 1 in 16

candidiasis 
titre of 1 in 4 or less; isolates were obtained in four of these cases. Seven had associated infections; isolates were obtained from two of these.

The clinical findings in the men, results of smears of urethral material, of the LGVCFT, and details of the presence of associated infection are shown in relation to isolation of Chlamydia from urethral material (Table $\mathrm{X}$ ). Of the patients suffering from ocular infection due to TRIC agent, seven gave histories suggestive of urethritis; isolates were obtained from four of these. Patients in whose cases smears of urethral secretion contained more than an arbitrary limit of 50 polymorphonuclear leucocytes per high-power field, together with evidence of urethritis in the two-glass test of the urine, were said to have 'marked' 'non-specific' urethritis (NSU). Those in whose cases the smear of urethral secretion showed more than ten but less than fifty polymorphonuclear leucocytes per high-power field were said to have 'mild' NSU. Nine men suffering from ocular infection due to TRIC agent had 'marked' NSU; isolates were obtained from eight. Eight had 'mild' NSU; isolates were obtained from two. No isolates were obtained in the cases of the five men with no urethritis. Fourteen men suffering from ocular infection due to TRIC agent showed fixation when tested by the LGVCFT; isolates were obtained from eight.

Of the eleven men who were sexual contacts of women with ocular infection due to TRIC agent, two gave histories suggestive of urethritis; an isolate was obtained from one. Three had 'marked' NSU; isolates were obtained from two. Seven had 'mild' NSU; isolates were obtained from four. No isolate was obtained in the case of the one contact who had no urethritis. Two contacts showed low levels of fixation when tested by the LGVCFT; no isolates were obtained in these cases.

There was evidence of associated infection (candidiasis) in only one of the men examined (a patient suffering from ocular infection due to TRIC agent); no isolate was obtained in this case.

\section{Discussion}

The high rate of isolation of Chlamydia from genital material from patients suffering from ocular infection due to TRIC agent, particularly in the cases of women, suggests that the methods used for the collection of material and the technique of isolation in cell culture provide efficient means for demonstrating Chlamydia. When applied to men suffering from Reiter's disease, the same techniques resulted in few positive findings; thus 29 men suffering from Reiter's disease yielded only three isolates. However, the recent treatment with anti-chlamydial antibiotics that nineteen of the patients had received may explain this low yield, for the three isolates obtained were from the group of ten untreated patients; three in ten represents a rate of isolation comparable with that obtained in nonspecific urethritis (Dunlop, Vaughan-Jackson, Darougar, and Jones, 1972).

Nevertheless, no isolate was obtained from untreated women who were contacts of men who had already received treatment.

Results of the LGVCFT offer little evidence for implicating Chlamydia in Reiter's disease as only low titres were obtained, and even these results did not correlate with isolation of agent. In contrast, the micro-IF test in ten cases showed quite high titres in eight, including the two isolate-positive cases.

The presence of Chlamydia, as shown by isolation, was usually associated with abnormalities of the mucosa and purulent smears from the affected sites. This is to be expected if Chlamydia is a pathogen in the genital tract and rectum.

It is of interest that isolates were obtained from genital material from four women whose male partners were suffering from ocular infection due to TRIC agent, although that agent was not isolated from urethral material from these men. Two of the men had low-grade urethritis so it is possible that tests? failed to detect Chlamydia in them. It is also possible that the eyes of these four men were infected by contamination with genital material from their female consorts. Alternatively, they might have had urethral infection by Chlamydia which had already subsided.

\section{Summary}

Tests in cell culture were carried out on material collected from 29 men suffering from acute Reiter's disease; isolates were obtained from three of the ten men who had not received recent treatment with anti-chlamydial antibiotics. No isolate was obtained from patients who had received such treatment. Fourteen female sexual contacts of these men who were suffering from Reiter's disease were tested; Chlamydia was isolated from one. The LGVCFT showed low levels of fixation in eight of the 28 men tested, including two of those who were isolatepositive. Ten patients suffering from Reiter's disease were tested by the micro-IF test, and titres of 1 in 16 or more were obtained in eight. In the two isolatepositive cases that were tested the titres were 1 in 32 and 1 in 128.

Genital and rectal material was tested from 23 women suffering from ocular infection due to TRIC agent; isolates of Chlamydia were obtained from the 
cervix in nineteen cases and the rectum in eleven. 22 men suffering from ocular infection due to TRIC agent were examined; isolates were obtained from urethral material from ten. Eleven male sexual contacts of women suffering from ocular infection due to TRIC agent were examined; isolates were obtained from urethral material from six. Nineteen female contacts of men suffering from ocular infection due to TRIC agent were examined; isolates were obtained from cervical material from eight.

There was a relationship between abnormal findings and the isolation of Chlamydia, as is to be expected if Chlamydia is a pathogen in the genital tract and rectum.

We are grateful to our colleagues who referred patients for investigation; to Dr. A. E. Wilkinson, Director of the V.D. Reference Laboratory, The London Hospital, for carrying out serological tests for syphilis, and cultures for bacteria, Trichomonas vaginalis, and Candida; and to the late Prof. C. F. Barwell and to other staff of the Virus Laboratory, The London Hospital, for carrying out the LGVCFT.

We thank the London Hospital for financial support and the Research and Development Division of the Department of Health and Social Security for a grant in support of the laboratory work at the Institute of Ophthalmology.

\section{References}

Barwell, C. F., Dunlop, E. M. C., and Race, J. W. (1967) Amer. F. Ophthal., 63, 1527

Darougar, S., Dwyer, R. St. C., Treharne, J. D., HARPER, I. A., Garland, J. A., and JONES, B. R. (1971a) In 'Trachoma and Related Disorders', ed. R. L. Nichols, p.445. Excerpta Medica, Amsterdam and New York

—, Jones, B. R., Kinnison, J. R., Vaughan-JaCkson J. D., and Dunlop, E. M. C. (1972) Brit. F. vener. Dis., 48, 416

—, Kinnison, J. R., and Jones, B. R. (1971a) 'Trachoma and Related Disorders', ed. R. L. Nichols, p.63. Excerpta Medica, Amsterdam and New York

,,--- (1971b) Idem, p.501

Dunham, J., Rock, J., and Belt, E. (1947) f. Urol. (Baltimore), 58, 212

Dunlop, E. M. C., Al-Hussaini, M.K., Garland, J. A., TREHARNe, J. D., HARPER, I. A., and Jones, B. R. (1965) Lancet, 1, 1125, 1286

-, Freedman, A., Garland, J. A., Harper, I. A., JONES, B. R., RACE, W. R., Du TOIT, M. S., and TREHARNE, J. D. (1967) Amer. F. Ophthal., 63, 1073

-, Hare, M. J., Darougar, S., and JoNes, B. R. (1971) 'Trachoma and Related Disorders', ed. R. L. Nichols, p.494. Excerpta Medica, Amsterdam and New York

,,,--- and RICE, N. S. C. (1969) f. infect. Dis., 120, 463
- Jones, B. R., and Al-Hussaini, M. K. (1964)

Brit. F. vener. Dis., 40, 33

- Vaughan-Jackson, J. D., and Darougar, S. (1972) Ibid., 48, 421

,,,--- , and JONES, B. R. (1972) Ibid., 48, 425

Gordon, F. B., HaRPER, I. A., QUAN, A. L., TREHARNe,

J. D., DwYer, R. St. C., and GarLand, J. A. (1969)

f. infect. Dis., 120, 451

-, MAgruder, G. B., QuAN, A. L., and ARM, H. G. (1963) Proc. Soc. exp. Biol. Med. (N.Y.), 112, 236

HARPER, I. A., Dwyer, R. St. C., Garland, J. A., Jones, B. R., Treharne, J. D., Dunlop, E. M. C., Freedman, A., and RACE, J. W. (1967) Amer. F. Ophthal., 63, 1064 SCHACHTER, J. (1971) Ibid., 71, 857

-, Barnes, M. G., Jones, J. P., Engleman, E. P., and MeYER, K. F. (1966) Proc. Soc. exp. Biol. (N.Y.), 122, 283

Siboulet, A., and Galistin, P. (1962) Brit. F. vener. Dis., 38, 209

WANG, S. P. (1971) 'Trachoma and Related Disorders', ed. R. L. Nichols, p.273. Excerpta Medica, Amsterdam and New York

and Grayston, J. T. (1970) Amer. F. Ophthal., 70, 367

, - (1971) 'Trachoma and Related Disorders', ed. R. L. Nichols, p.305. Excerpta Medica, Amsterdam and New York

\section{Infection chlamydiale}

Résultats de la recherche de Chlamydia chez les malades atteints de maladie de Reiter aigüe comparés avec le résultat de ces recherches dans les voies génitales et le rectum de malades présentant une infection oculaire due à l'agent TRIC

\section{SOMMAIRE}

Des épreuves en cultures cellulaires furent pratiquées à l'aide de matériel obtenu chez 29 hommes atteints de maladie de Reiter aigüe; des Chlamydia furent isolés chez 3 des 10 hommes qui n'avaient pas reçu récemment des antibiotiques anti-chlamydia. Aucun isolement ne fut obtenu chez les malades qui avaient reçu un tel traitement. On a examiné 14 femmes, partenaires sexuelles de ces hommes atteints de maladie de Reiter; Chlamydia fut isolé pour l'une d'entre elles. L'épreuve de fixation du complément avec l'antigène lymphogranulomateux montra de faibles taux de fixation chez 8 des 28 hommes étudiés, comprenant 2 de ceux chez lesquels l'isolement était positif. Dix malades atteints de maladie de Reiter furent examinés en épreuve de micro-IF et des titres de $1 / 16$ ou plus furent obtenus chez 8. Dans les deux cas où l'isolement avait été positif, les titres furent de 1/32 et de $1 / 128$.

Du matériel provenant des voies génitales et du rectum fut testé chez 23 femmes atteintes d'affections oculaires dues à l'agent TRIC; Chlamydia fut isolé du col dans 19 cas et du rectum dans 11 . Vingt-deux hommes atteints d'infection oculaire due à l'agent TRIC furent examinés, Chlamydia fut isolé du matériel urétral chez $10 \mathrm{~d}$ 'entre 
eux. Onze hommes partenaires sexuels de femmes atteintes d'infection oculaire due à l'agent TRIC furent examinées; l'isolement fut positif à partir du matériel urétral pour 6 d'entre elles. Dix-neuf femmes contacts d'hommes atteints d'affection oculaire due à l'agent
TRIC furent examinées; les isolements furent positifs à partir du matériel cervical pour 8 d'entre elles.

Il y a une relation entre les troubles cliniques et l'isolement du Chlamydia comme on peut s'y attendre si Chlamydia est pathogène dans les voies génitales et le rectum. 